\title{
PENGENALAN EKSPRESI WAJAH PENGGUNA ELEARNING MENGGUNAKAN ARTIFICIAL NEURAL NETWORK DENGAN FITUR EKSTRAKSI LOCAL BINARY PATTERN DAN GRAY LEVEL CO-OCCURRENCE MATRIX
}

\author{
Husdi \\ Mr.husdi@yahoo.com \\ Universitas Ichsan Gorontalo
}

\begin{abstract}
Abstrak
Pembelajaran eLearning merupakan sistem pembelajaran berbasis elektronik yang terdiri dari berbagai domain teknologi pembelajaran seperti desain, pengembangan, pemanfaatan, pengelolaan, dan penilaian proses dan sumber belajar elektronik, interaksi pemelajar merupakan kelemahan yang harus diperhatikan dalam pembelajaran eLearning, salah satunya dengan pengenalan ekspresi wajah pengguna eLearning. Ekspresi wajah dapat dikenali berdasarkan perubahan fitur penting wajah sebagai parameter yaitu pada mata, alis, mulut dan dahi, namun dalam penelitian ini dibatasi pada objek mata dan mulut sebagai parameter untuk pengenalan ekspresi wajah. Pada tahapan fitur ekstraksi digunakan LBP (Local Binary Pattern ) dan GLCM (Gray Level Coocurancy Matrix) untuk mendapatkan nilai-nilai parameter yang akan dijadikan inputan pada klasifikasi yaitu Contrast, Correlation, Energi dan Homogenity. Selanjutnya pada tahap klasifikasi digunakan algoritma Artificial Neural Network untuk mengenali ekspresi wajah. Ekspresi Wajah yang berhasil dikenali adalah Neutral, Smile/happy, Tired/Sleepy dengan akurasi tertinggi yang didapatkan adalah $88,89 \%$.
\end{abstract}

Kata kunci: eLearning, Fitur Ekstraksi, Klasifikasi, LBP, GLCM, ANN.

ILKOM Jurnal IImiah work is licensed under a CCA-SA 4.0 International License.

\section{Pendahuluan}

Pembelajaran eLearning merupakan sistem pembelajaran berbasis elektronik yang terdiri dari berbagai domain teknologi pembelajaran seperti desain, pengembangan, pemanfaatan, pengelolaan, dan penilaian proses dan sumber belajar elektronik agar terjadi proses belajar[1]. Peserta didik dan pendidik tidak harus bertatap muka secara langsung untuk melakukan proses pembelajaran. Permasalahan-permasalahan yang masih dihadapi pada pembelajaran elearning adalah eLearning strategy, content, management, dan evaluation. Penelitian-penelitian untuk menyelesaikan masalah tersebut masih jarang dilakukan, salah satu peran komputasi cerdas untuk menyelesaikan masalah tersebut, khususnya pada eLearning Strategy adalah seperti tercantum dalam gambar berikut [2]:

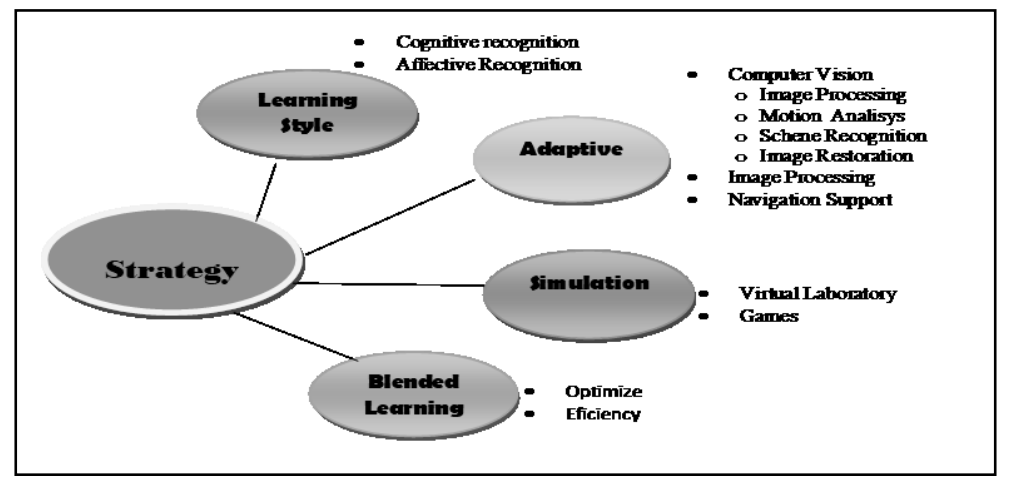

Gambar 1 eLearning Strategi [2]

Sistem adaptive eLearning tentunya tidak lepas dari berbagai macam hambatan dan permasalahan salah satunya adalah keberagaman pengetahuan yang dimiliki oleh peserta didik dan gaya belajar yang berbeda. Keduanya harus diperhatikan untuk mengadakan evaluasi dan peningkatan pembelajaran yang lebih baik[3]. Selain itu interaksi pemelajar merupakan kelemahan yang harus diperhatikan dalam pembelajaran eLearning. Salah satunya dengan pengenalan ekspresi wajah pengguna eLearning. Penelitian yang dilakukan oleh May-Ping Loh, et al/[4], meneliti tentang 
pengenalan ekspresi wajah pengguna elearning. Pada tahapan fitur ekstraksi menggunakan algoritma Gabor Wavelet sedangkan pada tahap klasifikasi menggunakan Algoritma Back Propagation Neural Network, hasil dari penelitian tersebut mengklasifikasikan 4 jenis ekspresi wajah pengguna eLearning yaitu netral, senyum, bingung, mengantuk/lelah. Pada hasil evaluasi didapatkan akurasi rata-rata adalah $83,75 \%$ dan hasil ini masih dibawah harapan peneliti tersebut.

Berdasarkan latar belakang masalah secara umum maka dapat dirumuskan bahwa Adaptive eLearning System belum menerapkan strategi pembelajaran yang mampu mengenali ekspresi wajah pemelajar berdasarkan kondisi mata dan mulut. Sedangkan Permasalahan spesifik (research gap) yang diangkat dalam penelitian adalah pengenalan ekspresi wajah pemelajar masih memiliki tingkat akurasi yang rendah, yang dapat mengakibatkan kurang optimalnya kinerja dari sistem pengenalan ekspresi wajah pemelajar, Penelitian ini diharapkan dapat memberikan sumbangsih pemikiran bagi upaya pencarian solusi terhadap permasalahan yang berhubungan dengan pembelajaran eLearning khususnya melalui pengenalan ekspresi wajah pemelajar, sehingga menghasilkan strategi pembelajaran yang lebih efektif dan efisien

\section{Tinjauan Pustaka}

\subsection{Penelitian Yang Relevan}

Penelitian yang dilakukan oleh May-Ping Loh, et all[4], meneliti tentang pengenalan ekspresi wajah pengguna elearning, dalam penelitian tersebut dikatakan bahwa keenam emosi dasar (bahagia, terkejut, marah, jijik, sedih dan takut) yang diusulkan oleh Ekman, tidak digunakan dalam pengenalan ekspresi eLearning, sehingga mengusulkan 4 ekspresi pelajar yaitu netral, senyum, bingung dan mengantuk atau lelah, dengan menggunakan Gabor Wavelet untuk ekstraksi fitur wajah, dan Backpropagation Neural Network untuk klasifikasi ekpresi wajah. Berikut ini merupakan gambar dari arsitekstur yang diusulkan

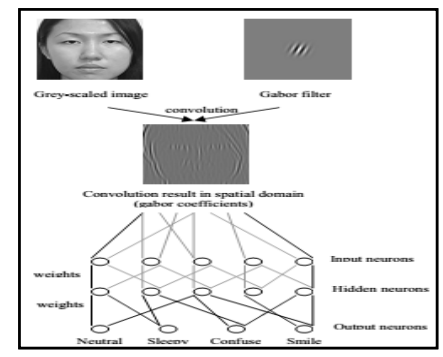

Gambar 2 Arsitektur dari Penelitian May-Ping Loh, et al/[4]

Hasil dari fitur ekstraksi dengan Gabor Wavelet akan dijadikan masukan pada lapisan pertama Neural Network, kemudian diteruskan pada lapisan kedua. Untuk menghitung akurasi, hasil yang diperoleh dari lapisan output dibandingkan dengan target output. Sehingga pada tahap evaluasi total rata-rata akurasi pengenalan ekspresi wajah adalah $83,75 \%$.

\subsection{Landasan Teori}

Menurut Ekman emosi dasar pada manusia terdiri dari 6 ekspresi wajah seperti bahagia, terkejut, marah, jijik , sedih, dan takut[5], namun dalam penelitian may-ping-loh et al. Dikatakan bahwa keenam ekspresi dasar tersebut tidak sesuai dengan ekspresi pemelajar pada pembelajaran eLearning, sehingga mengusulkan 4 ekspresi wajah untuk mendefinisikan ekspresi pemelajar seperti neutral, smile, confuse dan sleepy [4]. Ekspresi wajah tersebut dapat dikenali berdasarkan perubahan fitur penting wajah sebagai parameter yaitu pada mata, alis, mulut dan dahi [6].

Untuk ekspresi wajah neutral, smile, dan sleepy/tired, dapat ditentukan hanya berdasarkan parameter mata dan mulut saja, namun pada ekspresi wasjah confuse selain mata dan mulut yang dijadikan parameter juga harus ditentukan oleh perubahan pada alis [7], karena fokus penelitian hanya pada parameter mata dan mulut, maka jenis ekspresi yang yang dikenali pada pemelajar adalah ekspresi neutral, smile, sleepy/tired.pada tabel berikut ditampilkan jenis ekspresi yang akan dikenali berdasarkan parameter mata dan mulut.

\begin{tabular}{|c|c|c|c|}
\hline No & Ekspresi & Mulut & Mata \\
\hline 1 & Neutral & Mulut Tertutup normal [8] & $\begin{array}{l}\text { Mata terbuka normal dan } \\
\text { fokus pada layar [8] }\end{array}$ \\
\hline
\end{tabular}


ILKOM Jurnal Ilmiah Volume 8 Nomor 3 (Desember 2016)

\begin{tabular}{llll}
\hline 2 & Smile & $\begin{array}{l}\text { Bentuk Mulut melengkung ke atas [7] } \\
\text { (mulut tersenyum) }\end{array}$ & $\begin{array}{l}\text { Mata terbuka normal dan } \\
\text { fokus [7] }\end{array}$ \\
3 & Sleepy/tired & $\begin{array}{l}\text { Mulut terbuka dengan cepat[9] } \\
\text { Menguap (mulut terbuka) }\end{array}$ & Mata tertutup [9] \\
\hline
\end{tabular}

Salah satu operator tekstur analysis yang paling populer adalah Local Binary pattern $(L B P)$. LBP adalah ukuran tekstur invarian grayscale dihitung dari analisis lingkungan lokal $3 \times 3$ atas pusat pixel[10]. LBP ini didasarkan pada kode biner yang menggambarkan pola tekstur local. Nilai kedekatan diberi label menggunakan kode biner $\{0,1\}$ diperoleh dengan membandingkan nilai dari pusat nilai pixel, jika nilai abu-abu diuji di bawah nilais abu-abu pixel pusat, maka diberi label 0 , Operator rotasi tekstur invariant yang didefenisikan tekstur T pada diagram $3 \times 3$ dapat ditunjukkan pada matrix berikut :

\begin{tabular}{|c|c|c|}
\hline$g 3$ & $g 2$ & $g 1$ \\
\hline$g 4$ & $g c$ & $g 0$ \\
\hline$g 5$ & $g 6$ & $g 7$ \\
\hline
\end{tabular}$\quad$\begin{tabular}{|c|c|c|}
\hline 8 & 4 & 2 \\
\hline 32 & 64 & 128 \\
\hline
\end{tabular}

Gambar 3. Urutan Nilai Bobot LBP Pada Diagram 3x3 [11]

Metode GLCM (GrayLevel Cooccurrence Matrix) adalah salah satu cara mengekstrak fitur tekstur statistik orde kedua. GLCM menghitung urutan kedua statistik yang terkait dengan sifat gambar dengan mempertimbangkan hubungan spasial piksel [10]. Ilustrasi pembentukan GLCM atas citra dengan 4 tingkat keabuan (gray level) pada jarak $\mathrm{d}=1$ dan arah $0^{\circ}$

\begin{tabular}{|l|l|l|l|l|l|l|l|l|l|}
\hline 0 & 0 & 1 & 1 & \multicolumn{3}{|c}{0} & 1 & 2 & 3 \\
\hline 0 & 0 & 1 & 1 & 0 & 2 & 2 & 1 & 0 \\
\hline 0 & 2 & 2 & 2 & 1 & 0 & 2 & 0 & 0 \\
\hline 2 & 2 & 3 & 3 & 2 & 0 & 0 & 3 & 1 \\
\hline & 3 & 0 & 0 & 0 & 1 \\
\hline
\end{tabular}

Gambar 4. Perhitungan Nilai Matrix Co-Occurrence

Untuk menentukan tekstur diperlukan beberapa fitur, fitur-fitur yang digunakan untuk menganalisis nilai GLCM yang diteliti adalah Fitur Homogenitas , Energi ,Entropi dan Kontrast [12][13].

Artificial Neural Network atau Jaringan Saraf Tiruan (JST) adalah suatu metode komputasi yang meniru sistem jaringan saraf biologis, metode ini menggunakan elemen perhitungan non-linier dasar yang disebut neuron yang diorganisasikan sebagai jaringan yang saling berhubungan, sehingga mirip dengan jaringan saraf manusia Neural Network merupakan suatu model kecerdasan yang diilhami dari struktur otak manusia dan kemudian diimplementasikan menggunakan program komputer yang mampu menyelesaikan sejumlah proses perhitungan selama proses pembelajaran berlangsung.

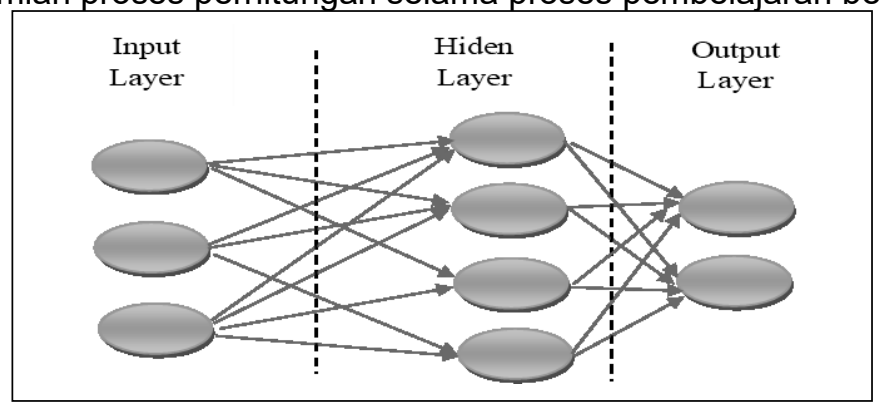

Gambar 5. Struktur Umum Backpropagation [14].

Perambatan galat mundur (Backpropagation) adalah sebuah metode sistematik untuk pelatihan multiplayerjaringan saraf tiruan, metode ini memiliki dasar matematis yang kuat, obyektif dan algoritma ini mendapatkan bentuk persamaan dan nilai koefisien dalam formula dengan meminimalkan jumlah kuadrat galat error melalui model yang dikembangkan (training set) [14].Neural network Backpropagation merupakan sebuah jaringan Neural Network yang bersifat supervised (Setiawan, 
2003), dimana diperlukan data training dalam prosesnya. Jaringan dalam Backpropagation bersifat multilayer, jadi minimal terdapat sebuah input layer, hidden layer dan, output layer.

Pengujian bertujuan untuk mempresentasikan hasil dari data yang diuji, pada tahap pengujian dilakukan perhitungan akurasi. Pengujian hasil eksperimen yang dilakukan berupa pengukuran akurasi bedasarkan prosentase keberhasilan pengenalan ekspresi wajah. Validasi hasil yang didapatkan adalah tabel pengukuran confusion matriks. Confusion matrix memberikan keputusan yang diperoleh dalam training dan testing[28], Confusion matrix memberikan penilaian dalam performance klasifikasi berdasarkan objek dengan benar atau salah. Pada proses klasifikasi pengukuran dilakukan dengan menggunakan confussion matrix, sebagaimana di ketahui confussion matrix merupakan sebuah pendekatan yang sangat baik dan mudah dalam penggunaannya untuk menganalisa seberapa baik pengklasifikasian yang dilakukan [14] untuk memperoleh empat nilai True Positive, False Negative, False Positive, dan True Negative.

True positive (TP) menunjukkan citra teridentifikasi secara tepat sesuai dengan kelasnya (positif). False positive (FP) merupakan citra yang seharusnya teridentifikasi dengan tepat pada kelasnya ternyata dalam proses klasifikasi namun salah dalam mengidentifikasi. True negatif (TN) merupakan citra yang bukan anggota kelas tersebut teridentifikasi tepat bukan anggota kelas tersebut (negatif). False negatif (FN) menunjukkan citra yang seharusnya bukan anggota dari klas tersebut teridentifikasi sebagai anggota kelas tersebut [15]. Confusion matrix menghitung akurasi dengan menghitung kumulatif dari jumlah prediksi yang benar dibagi dengan jumlah dari prediksi yang benar ditambah dengan prediksi yang salah. Perhitungan dirumuskan sebagai berikut :

$$
\text { Akurasi }=\frac{\sum \text { data uji yang dikenali }}{\sum \text { data uji }} * 100 \%
$$

\section{Metode}

Penelitian ini menggunakan data berupa video dengan objek peserta didik berupa video of-fline. Video tersebut merepresentasikan pengguna eLearning ketika mengikuti pembelajaran secara on-line. Data yang digunakan dari video tersebut didapatkan dari hasil segmentasi objek mata dan mulut, yang akan dijadikan parameter input dari penelitian ini.

1. Lokasi

Adapun tata cara pengambilan data video yang dilakukan seperti dijelaskan berikut ini :

Pengambilan data video dilakukan pada ruangan (indoor) dengan kondisi pencahayaan normal.

2. Posisi dan perangkat kamera yang digunakan

Kamera yang digunakan untuk pengambilan data adalah kamera webcam dengan posisi frontal terhadap pemelajar yang sedang berinteraksi dengan sistem eLearning

3. Skenario

Data video yang digunakan untuk eksperimen pada penelitian ini diatur sedemikian rupa hingga setiap adegan atau ekspresi yang dilakukan oleh pemelajar tampak natural.

Eksperimen yang dilakukan pada penelitian ini adalah dengan menggunakan tools matlab, dimana langkah-langkahnya seperti pada gambar, data yang digunakan pada penelitian ini dibatasi, pada objek mata dan mulut.

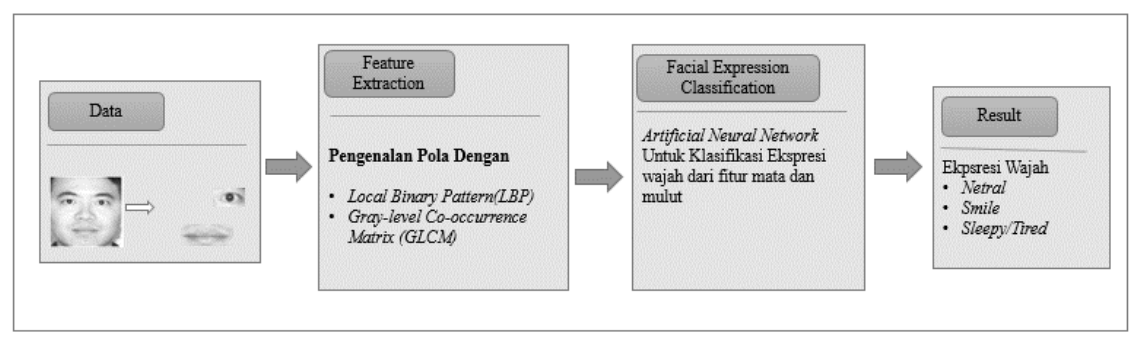

Gambar 6. Blok Diagram Model Yang diusulkan

Untuk mengevaluasi metode-metode yang telah diterapkan digunakan suatu metode tersendiri yaitu metode confusion matrix.Setelah metode diuji akan dihasilkan suatu persentase yang menunjukan tingkat keakuratan. Tingkat keakuratan ini dapat diukur dengan membandingkan ekspresi wajah yang berhasil dikenali dengan benar dengan jumlah keseluruhan data pengujian. 
Confusion matrix menghitung akurasi dengan menghitung kumulatif dari jumlah prediksi yang benar dibagi dengan jumlah dari prediksi yang benar ditambah dengan prediksi yang salah. Perhitungan dirumuskan sebagai berikut :

$$
\begin{gathered}
\text { Akurasi }=\frac{\sum \text { data uji yang dikenali }}{\sum \text { data uji }} * 100 \% \\
\text { Accuracy }=\frac{a+e+i}{(a+e+i)+(b+c+d+f+g+h)} * 100 \%
\end{gathered}
$$

\section{Hasil}

Langkah awal dari $\angle B P$ adalah menentukan nilai biner yang menggambarkan pola tekstur lokal, kode ini dibangun oleh thresholding dengan nilai abu-abu dari pusatnya. Nilai kedekatan diberi label menggunakan kode biner $\{0,1\}$ diperoleh dengan membandingkan nilai-nilai dari pusat nilai pixel, jika nilai abu-abu diuji di bawah abu-abu nilai pixel pusat, maka diberi label 0 , sebaliknya diberikan nilai 1 .

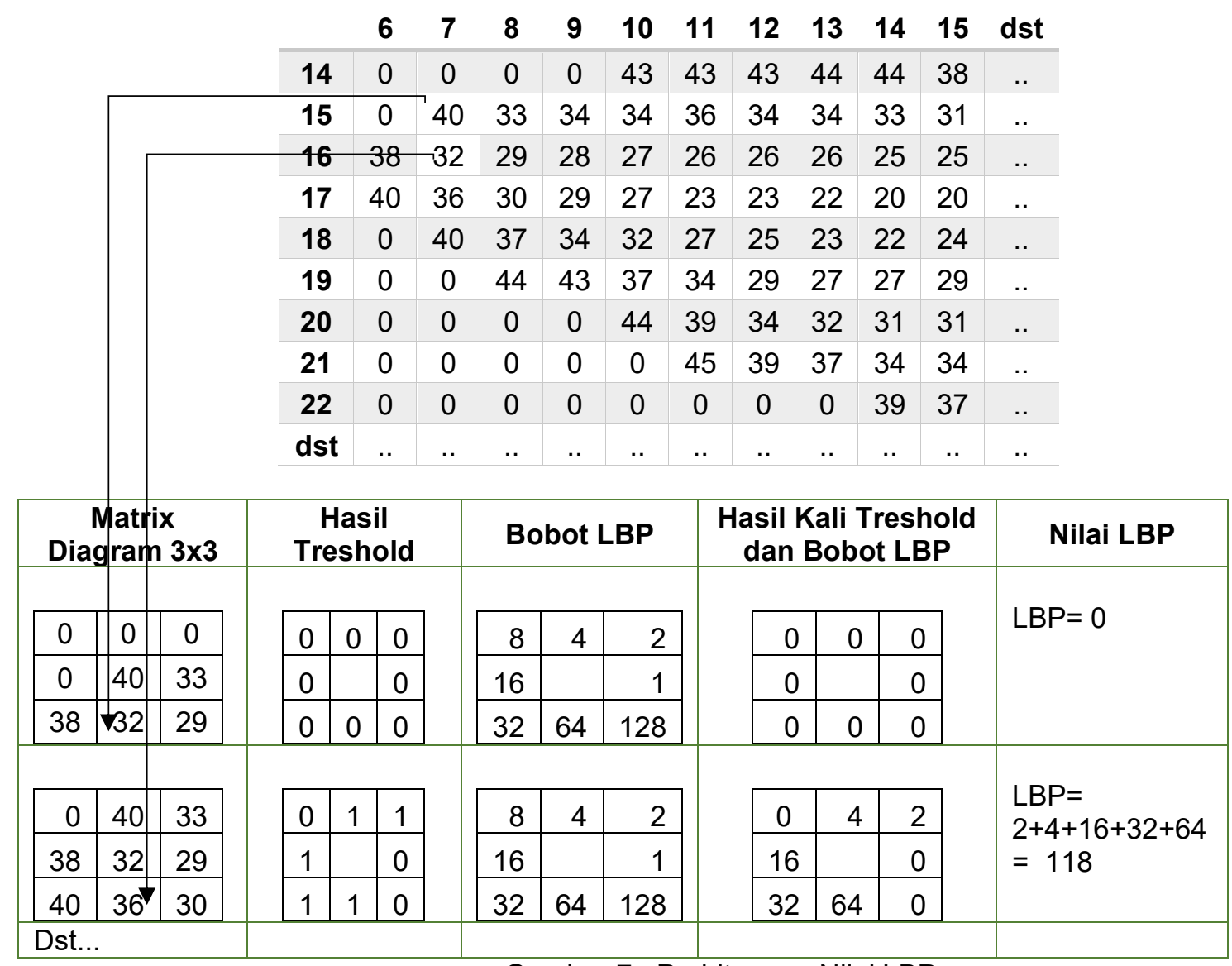

Gambar 7. Perhitungan Nilai LBP

Perhitungan nilai $\angle B P$ dilakukan sampai semua matrix terkonversi secara keseluruhan, Tabel berikut adalah hasil dari proses $\angle B P$ pada gambar 5 .

\begin{tabular}{|c|c|c|c|c|c|c|c|c|c|c|c|}
\hline.. & 6 & 7 & 8 & 9 & 10 & 11 & 12 & 13 & 14 & 15 & Dst \\
\hline 14 & 255 & 255 & 255 & 255 & 1 & 17 & 17 & 1 & 16 & 16 & $\ldots$ \\
\hline 15 & 255 & 0 & 49 & 1 & 23 & 14 & 31 & 30 & 30 & 30 & $\ldots$ \\
\hline 16 & 64 & 118 & 254 & 126 & 126 & 31 & 31 & 30 & 31 & 31 & $\ldots$ \\
\hline 17 & 0 & 88 & 248 & 248 & 252 & 255 & 254 & 126 & 255 & 255 & $\ldots$ \\
\hline 18 & 255 & 0 & 208 & 240 & 240 & 248 & 240 & 248 & 241 & 224 & $\ldots$ \\
\hline 19 & 255 & 255 & 0 & 16 & 208 & 240 & 240 & 241 & 241 & 224 & $\ldots$ \\
\hline 20 & 255 & 255 & 255 & 255 & 0 & 208 & 248 & 240 & 241 & 241 & $\ldots$ \\
\hline 21 & 255 & 255 & 255 & 255 & 255 & 0 & 24 & 16 & 209 & 241 & $\ldots$ \\
\hline
\end{tabular}

Tabel 2. Nilai LBP Dari Grayimage 


\begin{tabular}{|c|c|c|c|c|c|c|c|c|c|c|c|}
\hline 22 & 255 & 255 & 255 & 255 & 255 & 255 & 255 & 255 & 0 & 16 & $\ldots$ \\
\hline Dst & $\ldots$ & $\ldots$ & $\ldots$ & $\ldots$ & $\ldots$ & $\ldots .$. & $\ldots$ & $\ldots$ & $\ldots$ &.. & $\ldots$ \\
\hline
\end{tabular}

Setelah matrix nilai $L B P$ didapatkan maka nilai tersebut akan di jadikan kembali sebagai inputan pada poses GLCM, pembentukan GLCM atas citra pada jarak $d=1$ dengan arah $0^{\circ}$, arah atau sudut orientasi menyatakan hubungan dari pixel yang berdekatan dalam hal ini $0^{\circ}$ adalah hubungan pixel dari kiri ke kanan ataupun sebaliknya pada posisi horisontal. sehingga hasilnya seperti pada tabel 4.4 berikut ini :

Tabel 3. Matrix Co-Occurrence

\begin{tabular}{|c|r|r|r|r|r|r|r|r|r|r|r|r|r|r|}
\hline.. & $\mathbf{2 7}$ & $\mathbf{2 8}$ & $\mathbf{2 9}$ & $\mathbf{3 0}$ & $\mathbf{3 1}$ & $\mathbf{3 2}$ & $\mathbf{3 3}$ & $\mathbf{3 4}$ & $\mathbf{3 5}$ & $\mathbf{3 6}$ & $\mathbf{3 7}$ &.. & $\mathbf{2 5 5}$ \\
\hline $\mathbf{2 7}$ & 0 & 0 & 0 & 0 & 0 & 0 & 0 & 0 & 0 & 0 & 0 &.. & 0 \\
\hline $\mathbf{2 8}$ & 0 & 4 & 0 & 3 & 1 & 0 & 0 & 0 & 0 & 0 & 0 &.. & 0 \\
\hline $\mathbf{2 9}$ & 0 & 0 & 0 & 0 & 0 & 0 & 0 & 0 & 0 & 0 & 0 &.. & 0 \\
\hline $\mathbf{3 0}$ & 0 & 3 & 0 & 13 & 15 & 0 & 0 & 0 & 0 & 0 & 0 &.. & 0 \\
\hline $\mathbf{3 1}$ & 0 & 7 & 0 & 16 & 32 & 0 & 0 & 0 & 0 & 0 & 0 &.. & 0 \\
\hline $\mathbf{3 2}$ & 0 & 0 & 0 & 0 & 0 & 0 & 0 & 0 & 0 & 0 & 0 &.. & 0 \\
\hline $\mathbf{3 3}$ & 0 & 0 & 0 & 0 & 0 & 0 & 0 & 0 & 0 & 0 & 0 &.. & 0 \\
\hline $\mathbf{3 4}$ & 0 & 0 & 0 & 0 & 0 & 0 & 0 & 0 & 0 & 0 & 0 &.. & 0 \\
\hline $\mathbf{3 5}$ & 0 & 0 & 0 & 0 & 0 & 0 & 0 & 0 & 0 & 0 & 0 &.. & 0 \\
\hline $\mathbf{3 6}$ & 0 & 0 & 0 & 0 & 0 & 0 & 0 & 0 & 0 & 0 & 0 &.. & 0 \\
\hline.. &.. &.. &.. &.. &.. &.. &.. &.. &.. &.. &.. &.. & 0 \\
\hline $\mathbf{2 5 5}$ & 0 & 0 & 0 & 0 & 0 & 0 & 0 & 0 & 0 & 0 & 0 & 0 & 0 \\
\hline
\end{tabular}

Nilai Co-Occurrence merupakan langkah pertama dari proses $G L C M$, langkah selanjutnya nilai Co-Occurrence tersebut dicari nilai transpos, hasil dari nilai transpos dijumlahkan dengan nilai CoOccurrence dan akan menghasilkan nilai matrix yang simetris. Matriks yang telah simetris selanjutnya harus dinormalisasi elemen-elemennya yang dinyatakan dengan probabilitas atau nilai elemen untuk masing-masing sel dibagi dengan jumlah seluruh elemen spasial. Sehingga dihasilkan matriks GLCM yang ternormalisasi sebagai berikut

Sehingga nilai parameter GLCM yang didapatkan adalah sebagai berikut :

1. Energy $=0.543779$,

2. Kontras $=2.665810$

3. Homogenitas $=0.80033$

4. Correlation $=0.783331$

Dari proses feature ekstraksi ini maka nilai ciri fitur pada masing-masing variabel yang telah didapatkan berfungsi sebagai inputan pada proses klasifikasi ekspresi wajah, adapun variabel : mulut (contrast, energy, corelation, homogenity), mata (contrast, energy, corelation, homogenity).

Proses klasifikasi adalah tahapan untuk mengenali ekspresi wajah berdasarkan data fitur ekstraksi yang telah dipeoleh, pada penelitian ini terdiri dari 2 hiden layer dimana pada layer pertama berisi 20 neuron dan hiden layer kedua 3 neuron. Setiap neuron pada lapisan input maupun output akan terhubung dengan neuron pada lapisan tersembunyi melalui bobot dan fungsi aktivasi, fungsi aktivasi digunakan untuk menentukan keluaran suatu neuron. Nilai dari lapisan tersembunyi akan masuk menuju output melalui fungsi identitas (train/m).

Hasil dari Klasifikasi ANN tersebut akan menghasilkan keluaran berupa angka 1, 2 dan 3. Sesuai dengan target yang diberikan pada dataset training, selanjutnya dikonversi sesuai dengan ekpresi yang dikenali.

Tabel 4. Contoh Hasil Klasifikasi

\begin{tabular}{|c|c|c|c|}
\hline NO & Gambar & Data & $\begin{array}{c}\text { Hasil Pengenalan Ekspresi } \\
\text { Wajah }\end{array}$ \\
\hline 1 & Img_Pemelajar_1050.png &
\end{tabular}




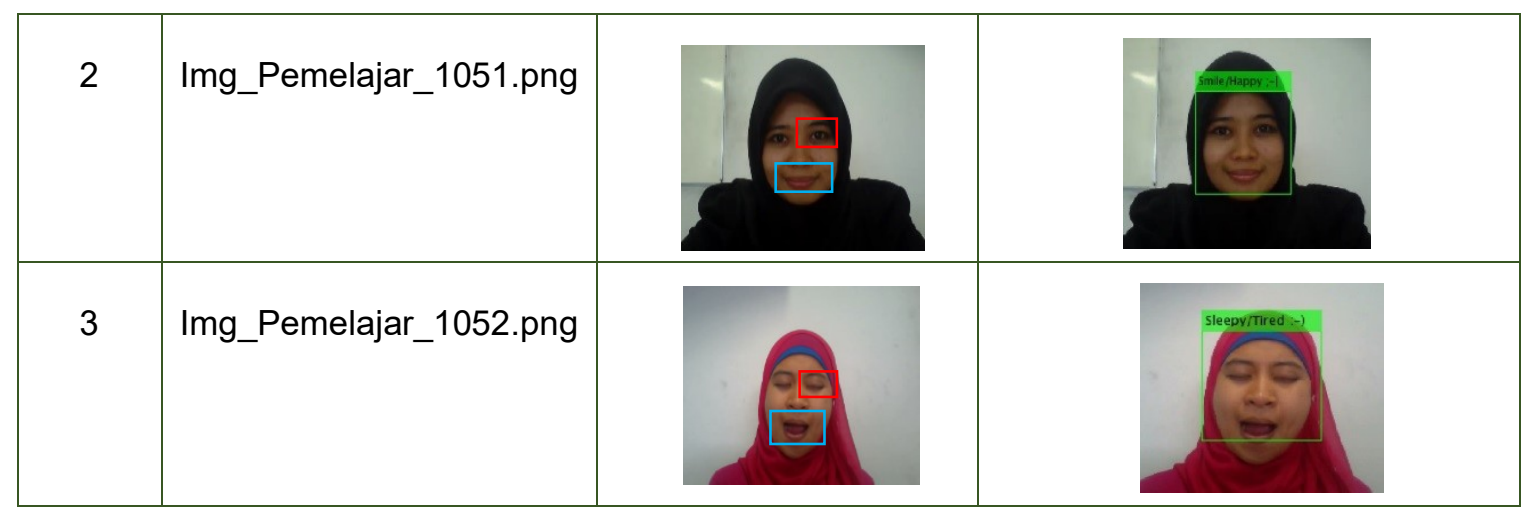

Proses pengenalan ekspresi wajah pada eksperimen ini diawali dengan feature ekstraksi yakni mengestrak fitur mata dan mulut dengan menggunakan $L B P$ dan GLCM, fitur ekstraksi yang baik akan meningkatkan akurasi hasil klasifikasi. Pada tahapan $L B P$ menggunakan Sampling Point $(P)=8$ dan Radius $=1$, sedangkan pada proses GLCM menggunakan Jarak $d=1$ dan arah $=0^{\circ}$, parameter yang telah didapatkan dari fitur mata dan mulut tersebut selanjutnya dijadikan inputan untuk Neural Network sebagai proses klasifikasi. Pengujian yang dilakukan sebanyak 4 kali dapat ditunjukkan dari grafik di bawah ini untuk fitur ekstraksi $L B P$ dan GLCM.

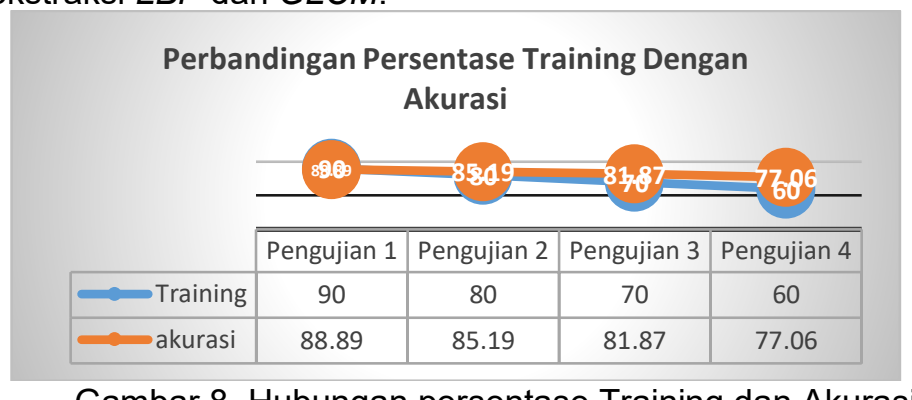

Gambar 8. Hubungan persentase Training dan Akurasi.

Pada gambar 8 diperlihatkan hubungan antara persentase training dan persentase akurasi, pengujian pertama dengan persentase training $90 \%$ didapatkan akurasi $88,89 \%$, dan pengujian keempat dengan persentase training $60 \%$ didapatkan akurasi $77,06 \%$, dengan demikian bahwa semakin banyak data training maka akurasi juga akan meningkat, dan demikian pula sebaliknya. Dari eksperimen dengan menggunakan fitur ekstraksi LBP dan GLCM, serta Backpropagation Neural Network sebagai klasifikasi, data yang digunakan pada pengujian dengan menggunakan metode tersebut, digunakan kembali pada metode yang digunakan pada penelitian sebelumnya yaitu oleh MayPing Loh, et all[7], dengan metode Gabor Wavelet sebagai fitur ekstraksi, dan Backpropagation Neural Network. Hasilnya dapat dilihat seperti pada gambar berikut ini.

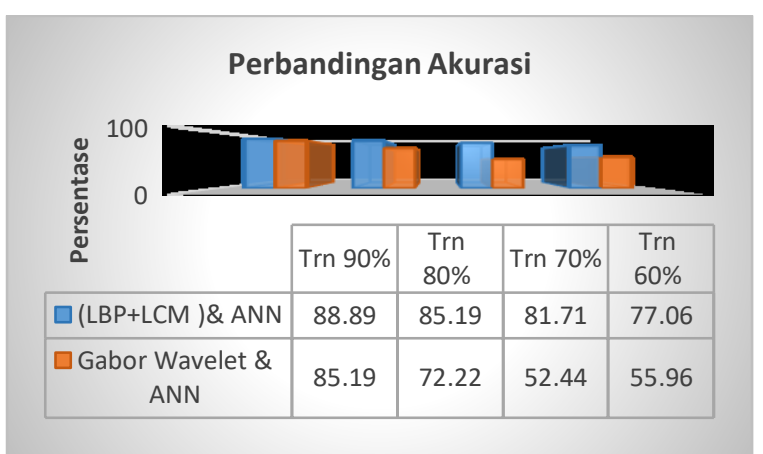

Gambar 9. Perbandingan Akurasi antara fitur ekstraksi LBP+GLCM dengan Gabor Wavelet.

Dari hasil penelitian menunjukkan bahwa penggabungan $L B P$ dan GLCM sebagai feature ekstraksi dan Artificial Neural Network dapat meningkatkan hasil pengenalan ekspresi wajah pemelajar lebih baik ditandai denan akurasi yang lebih baik. 


\section{Kesimpulan dan Saran}

Berdasarkan pengujian yang dilakukan pada hasil klasifikasi Artificial Neural Network menggunakan Local Binary Pattern (LBP) sebagai fitur ekstraksi orde pertama dan Gray Level CoOccurrence Matrix (GLCM) sebagai orde kedua pada proses pengenalan ekspresi wajah pengguna eLearning. Dapat disimpulkan bahwa Pengenalan ekspresi wajah pemelajar berdasarkan parameter mata dan mulut berhasil memperoleh akurasi yang lebih baik sehingga dapat digunakan untuk memberikan masukan dalam rekayasa Adaptive eLearning System, Pengujian yang dilakukan terhadap hasil klasifikasi Backpropagation Neural Network dengan fitur ekstaksi LBP dan GLCM akurasi tertinggi adalah $88,89 \%$, hasil tersebut lebih baik dari pada hasil klasifikasi dengan Backpropagation Neural Network dengan fitur ekstraksi Gabor Wavelet dengan akurasi tertinggi yang didapatkan adalah 85,19\%

Bagi peneliti selanjutnya yang ingin meneliti topik yang sama dengan penelitian ini agar berfokus pada penambahan parameter alis dan dahi untuk pengenalan ekspresi wajah lainnya. Penambahan jumlah dataset training yang lebih banyak dan bervariasi, sehingga bisa diterapkan pada objek atau pemelajar yang lebih beragam dan meningkatkan akurasi dari penelitan ini.

\section{Daftar Pustaka}

[1] Santosa, Stefanus. 2011. “Isu Krit. Pembelajaran di Perguruan. Tinggi Dengan Pendekatan Berbas. E-Learning, Makalah Disampaikan Dalam Workshop IT bagi Tenaga Pendidik di STAIN Kudus.

[2] Santosa, Stefanus. 2010. " eLearning Research Interest ", Makalah Disampaikan Dalam Workshop Kerjasama Penelitian Antar-Perguruan Tinggi Udinus Dan Utem.

[3] C. Limongelli, F. Sciarrone, M. Temperini, dan G. Vaste. 2006. "Adaptive Learning with the LSPlan System: A Field Evaluation”, IEEE Trans. Learn. Technol., vol. 2, no. 3, pp. 203-215.

[4] M. Loh, Y. Wong, dan C. Wong.2006. "Facial Expression Recognition for E-learning Systems using Gabor Wavelet \& Neural Network", Sixth IEEE Int. Conf. Adv. Learn. Technologi, pp. 523525.

[5] P. Ekman .1982.: Emotion in the Human Face. Cambridge - Cambridge University Press.

[6] S. Ghozali, B. Yusuf dan A. Jazidie .2011."Pengenalan Emosi Akademis menggunakan Jaringan Syaraf Tiruan untuk Mendukung Personalisasi Sistem E-learning" Institut Teknologi Sepuluh Nopember.

[7] M. Loh, Y. Wong dan C. Wong. 2005. "Facial expression analysis in e-learning systems - the problems and feasibility", Sixth IEEE Int. Conf. Adv. Learn. Technologi.

[8] E. Cerezo, I. Hupont, C. Manresa, J. Varona, S. Baldassarri, F. J. Perales, dan F. J. Seron, "RealTime Facial Expression Recognition for Natural Interaction" pp. 40-47.

[9] Kuo-An Hwang dan Chia-Hao Yang, "Automated Inattention and Fatigue Detection System in Distance Education for Elementary School Students ",School Students. Educational Technology \& Society, 12 (2), 22-35.

[10] Shervan Fekri Ershad, "Texture Classification Approach Based on Combination of Edge \& Cooccurrence and Local Binary Pattern", Int'I Conf. IP, Comp. Vision, and Pattern Recognition, IPCV'11.

[11] Timo Ojala, Matti Pietikäinen and T opi Maenpaa, "Gray Scale and Rotation Invariant T exture Classification with Local Binary Patterns" Machine Vision and Media Processing Unit Infotech Oulu, University of Oulu

[12] Ardianto Eskaprianda, R. Rizal Isnanto dan Imam Santoso, "Deteksi Kondisi Organ Pankreas Melalui Iris Mata Menggunakan Jaringan Syaraf Tiruan Metode Perambatan Balik dengan Pencirian Matriks Ko-Okurensi Aras Keabuan “ Transmisi, 13 (1), 2011, 33-38

[13] Adi Purnomo, Sulistyo Puspitodjati, "Aplikasi Pemrograman C\# Untuk Analisis Tekstur Kayu Parquet Dengan Menggunakan Metode GreyLevel Co-occurrence Matrix (GLCM)", Fakultas Teknologilndustri, Universitas Gunadarma

[14] F. Wave .2009. "Penerapan algoritma Backpropagation untuk klasifikasi musik dengan solo instrumen" Seminar Nasional Aplikasi Teknologi Informasi 2009 (SNATI 2009) Yogyakarta.

[15] Cucun Very Angkoso, Ingrid Nurtanio dan I Ketut Eddy Purnama, " Analisa Tekstur Untuk Membedakan Kista Dan Tumor Pada Citra Panoramik Rahang Gigi Manusia", Institut Teknologi Sepuluh November Surabaya, ISSN 2088-4796 